\title{
Parenting Goals among Moslem Parents in Bandung, Indonesia
}

\author{
Fitri Ariyanti Abidin, Juke R. Siregar, Poeti Joefiani, Rismijati E. Koesma \\ Faculty of Psychology, Padjadjaran University \\ Corresponding e-mail: fitri.ariyanti.abidin@unpad.ac.id
}

\begin{abstract}
Parenting goals can be seen as representatives of value in a society, since family are one of the important unit of socialization for children. What is perceived as important or unimportant to a society will be socialized in the family. Since value, belief and culture can differ from society to society, then the knowledge of parenting in a particular society needs to be studied. There are limited study about family and parenting practices in south East Asian countries. This study was aimed to describe parenting goals among Moslem parents in Bandung, Indonesia. One hundred and four parents was participated in present study. The mean age of mother was 36.57 ( $\mathrm{SD}=4.92$, range 25-52). The mean age of father was 39.17 ( $\mathrm{SD}=7.31$, range 26-71). The participants comes from various background (ethnicity, educational background, stage of family development). Open ended question about parenting goal they want to achieve was given, the participants may write more than one answer. 334 answer then recorded and coded by theme (thematic analysis) through two stages. The data analyzed using manual technique, then calculated by its percentage. The results showed that religious qualities (sholeh / sholehah and perform religious obligations) founded as a prominent parenting goal. Relational qualities (such as socialization skills, respect for parents and others, tolerance, sharing and empathy) are not so prominent compared to the personal qualities
\end{abstract}

Keywords: $\quad$ parenting goals, moslem parents, Indonesia

\section{INTRODUCTION}

Parenting is a complex and dynamic process. It is the mechanism through which a child learns appropriate and inappropriate behavior, experiences right and wrong choices in decision-making, acquires skills; understand roles and norms of a community (Pérez \& Cumsille, 2012). Changing that happens in developmental stage of parents and children and also in social context, was the two reasons why parenting is a complex and dynamic process. Parenting goal, one of basic aspect of parenting, influenced by many factors, such as attitudes and ideologies of the culture as a macro system (Bronfrenbenner, 1979 in Steinberg, 2014). The differences in parenting goals will affect the differences in parenting styles and parenting practices. Most studies about parenting comes from western country. There still limited study conducted in nonwestern country, especially in south East Asia which has different life context from the western country. This study aims to fill the gap by assessing parenting goals in Indonesia, South East Asia's most populated country. In Indonesia, we can find three generation of a family living together in a house. Enrich with many ethnicity, religions and development in economic as a country, policy in Indonesia changing frequently. Islam as the major religion in Indonesia, have it values shaping the perception of Indonesian parents.

As well as, it effects the context of family development, it is interesting to understand parent's perception regarding their parenting goals nowadays. As a country with collectivist culture, this study was also intended to find out whether this characteristics of culture affect parenting goals.

\section{LITERATURE REVIEW}

Culture influences parenting patterns and child development from very early in infancy through such factors as when and how parents care for infants, the extent to which parents permit infants freedom to explore, how nurturing or restrictive 
parents are, which behaviors parents emphasize, and so forth (Bornstein, 2002 ).

In toddler care, cultures differ in whether their ultimate goal is interdependence or independence and to whom (mother versus child) they assign the leading role in the push for separateness (Greenfield and Suzuki, 1998 in Bornstein, 2002). Whereas people in North America and Western Europe tend to see the drive for autonomy as coming from the toddler who needs to push away from the mother, people in rural village communities from subSaharan Africa, South America, and Central America place the mother in charge of creating psychological separation. Cultures appear to differ in the age at which they expect mastery of these competencies by the child, their order, and how significant each is considered in defining the child's maturity. Moreover, cultures differ in whether the ultimate goal of socialization is autonomy or interdependence and whether they put on the parent or on the child the responsibility for leading the way toward the child's more self-reliant functioning. Stance-against the toddler's expected resistance (Edwards, 1989 in Bornstein, 2002). The importance of culture in understanding parenting has been recognized in many Asian societies (Ontal \& Mastergeorge, 2010).

One construct that so popular in cross-cultural psychology is individualism and collectivism. Collectivist culture emphasize the interdependence of every human and some collectives (e.g. family, tribe, and nation). Individualist culture emphasize that people are independent of their groups. One of the more important attributes that distinguishes different kinds of individualism and collectivism is the acceptance of a horizontal and or vertical perspectives. Horizontal cultures emphasize equality, vertical cultures emphasizes hierarchy (Triandis in Matsumoto, 2001).

\section{METHOD AND RESULT}

\subsection{Method}

Survey technique was used in this study. One hundred and four parents were conveniently recruited from an Islamic school in Bandung. Demographic characteristics showed that participants come from various background, as seen in table 1:
Table 1. Participant demographic characteristics

\begin{tabular}{|c|c|}
\hline Variables & $\mathrm{N}=104$ \\
\hline $\mathrm{N}$ & 104 \\
\hline \multicolumn{2}{|l|}{ Mother Age } \\
\hline Range (years) & $25-52$ \\
\hline Mean (years) & 36.57 \\
\hline SD (years) & 4.92 \\
\hline \multicolumn{2}{|l|}{ Father Age } \\
\hline Range (years) & $26-71$ \\
\hline Mean (years) & 39.17 \\
\hline SD (years) & 7.31 \\
\hline \multicolumn{2}{|l|}{ Mother education } \\
\hline High school (\%) & 10 \\
\hline College $(\%)$ & 14 \\
\hline University (\%) & \\
\hline \multicolumn{2}{|l|}{ Father education } \\
\hline \multicolumn{2}{|l|}{ High school (\%) } \\
\hline College $(\%)$ & 9 \\
\hline University (\%) & 9 \\
\hline \multicolumn{2}{|l|}{ Mother ethnicity } \\
\hline \multicolumn{2}{|l|}{ Sundanese $(\%)$} \\
\hline Javanese $(\%)$ & 52 \\
\hline Other $(\%)$ & 7 \\
\hline Not filled $(\%)$ & 23 \\
\hline \multicolumn{2}{|l|}{ Father ethnicity } \\
\hline \multicolumn{2}{|l|}{ Sundanese $(\%)$} \\
\hline Javanese $(\%)$ & 44 \\
\hline Other $(\%)$ & 16 \\
\hline Not filled $(\%)$ & 25 \\
\hline \multicolumn{2}{|l|}{ Stage of family development } \\
\hline Family with preschool children (\%) & \\
\hline Family with school children $(\%)$ & 25 \\
\hline Family with teenager $(\%)$ & 53 \\
\hline Family launching young adults (\%) & 20 \\
\hline \multicolumn{2}{|l|}{ Member of family lives with children } \\
\hline Mother and father (\%) & \\
\hline Mother, father, grandparent $(\%)$ & 53 \\
\hline \multirow{2}{*}{ Mother, father, other relative (\%) } & 31 \\
\hline & 12 \\
\hline
\end{tabular}

The instrument used in this study is a questionnaire consisting of demographic questions and open ended questions to capture parenting goals. The participants were asked their expectation regarding quality of the children as a result of their parenting practices. The participants can write more than one answer, in space provided. The data was analyzed through two stages: (1) in-vivo coding and (2) broader themes coding (Creswell \& Clark, 2007). The coding was done manually.

\subsection{Result}

There were total of 334 answers obtained from the participants concerning parenting goals. The answers then categorized by key word to 17 
categories. Answers counted in each category then summarized as presented in Table 2:

Table 2. Keyword-based categorization

\begin{tabular}{lrr}
\hline Quality of Child (Goal of Parenting) & $\mathrm{N}$ & $\%$ \\
\hline 1. Sholih/solehah \& practicing religious rules & 87 & 26 \\
2. Autonomy, doing their obligation by internal & & \\
motivation & 59 & 18 \\
3. Smart & 27 & 8 \\
4. Well mannered & 20 & 6 \\
5. Discipline & 15 & 4 \\
6. Brave & 13 & 4 \\
7. Achieve academic skill & 13 & 4 \\
8. Socialization & 13 & 4 \\
9. High self confidence & 12 & 4 \\
10. Honest & 11 & 3 \\
11. Creative & 11 & 3 \\
12. Obedience and respect to parents & 11 & 3 \\
13. Tolerance, caring, sharing & 11 & 3 \\
14. Maturation in managing emotion & 10 & 3 \\
15. Responsible & 9 & 3 \\
16. Happy & 8 & 2 \\
17. Empathy & 4 & 1 \\
\hline
\end{tabular}

Table 2 showed that religious related quality topped the other quality in parenting goals where autonomous came after it. It follows that socializing children becoming religious and autonomous were important goals in Indonesia's parent practices. As most Moslem populated country, religious values affect broad aspects of Indonesian lives, including parenting practices.

These 17 theme-based categories then arranged into 3 broader themes; personal quality, religious quality and relational quality. Table 3 showed the proportion of these 3 broader themes.

Table 3. Categorization of parents' responses about parenting goal

\begin{tabular}{lll}
\hline Quality of Child (Goal of Parenting) & N & $\%$ \\
\hline Personal qualities & 188 & 56 \\
Religious qualities & 87 & 26 \\
Relational qualities & 59 & 18 \\
\hline
\end{tabular}

Using concept of individualist vs. collectivist culture and perspective of horizontal vs. vertical (Triandis, in Matsumoto, 2001), Indonesia is a country with vertical collectivism; especially in parent-child relation. But in this study, parents expectation regarding interpersonal quality of their children (well mannered, good socialization, obedience and respect to parents, tolerance, caring, sharing and empathy) are less in amount compare to parents expectation regarding religious and personal quality (doing their activity independently, smart, discipline, brave, achieve academic skills, have a high self-confidence, honest, creative, mature in managing emotion, responsible and happy).

\section{CONCLUSIONS}

Parenting goals gave a direction to parenting practice in a particular society. In the term of knowledge, it gives us explanation why parents apply a specific behavior in their childrearing. From current study, we can conclude that even though Indonesia practice vertical-collectivism culture, but personal qualities and religious qualities was important parenting goal, compared with relational qualities.

\section{REFERENCES}

Creswell, J. W., \& Plano, C. V. L. (2007). Designing and conducting mixed methods research. Thousand Oaks, Calif: SAGE Publications.

Matsumoto, D. R. (2001). The handbook of culture \& psychology. New York: Oxford University Press. Chicago Ontal. L. \& Mastergeorge, A. (2010). Culture and Parenting, a guide for delivering parenting curriculums to diverse families. Families with young children workgroup.

M.H. Bornstein (Ed.), (2002). Handbook of parenting: Children and Parenting. 2nd ed. Vol. 1

Pérez, J. C., \& Cumsille, P. (2012). Adolescent temperament and parental control in the development of the adolescent decision making in a Chilean sample. Journal of Adolescence, 35(3), 659669.http://dx.doi.org/10.1016/j. adolescence.2011.09.002

Steinberg, L (2014). Adolescence. Tenth Edition. Newyork. McGraw-Hill International Edition. 